\title{
A CONFISSÃO E OS SEUS CONSECTÁRIOS NO PROCESSO PENAL BRASILEIRO CONTEMPORÂNEO
}

\author{
CONFESSION AND ITS CONSECRATORS IN THE CONTEMPORARY \\ BRAZILIAN CRIMINAL PROCESS
}

Rodrigo Aparecido dos SANTOS ${ }^{1}$

ISSUE DOI: $10.21207 / 1983.4225 .448$

\begin{abstract}
RESUMO
Não obstante a aparente sedimentação na doutrina e na jurisprudência do instituto da confissão no processo penal, é certo que, em uma análise mais acurada, podemos perceber diversas contradições e, portanto, temos como objetivo apontá-las, bem como adotar o melhor posicionamento, sempre com argumentos plausíveis e coerentes com a sistemática do ordenamento processual penal atual. No capítulo inicial, é abordada a confissão e suas nuances, quais sejam, o conceito, o conteúdo, a natureza jurídica, os requisitos - de ordem formal e material -, classificações de maior importância prática, a problemática do silêncio como forma de confissão no processo penal brasileiro e, por fim, as principais características. Por seu turno, no capítulo seguinte, o valor probatório da confissão nos dias atuais é o objeto de estudo. Por derradeiro, parte-se, no último capítulo, para uma análise dos principais corolários da confissão no processo penal brasileiro, com destaque para a circunstância atenuante genérica prevista no artigo 65, inciso III, alínea "d", do Código Penal, e para o crime de autoacusação falsa, estatuído no artigo 341 do mesmo diploma legal.
\end{abstract}

Palavras-chave: Confissão. Prova. Processo Penal.

\section{ABSTRACT}

1 Graduado em Direito pela Faculdade de Direito de Franca (2016), curso-tecnicoprofissionalizantepela ETEC Professor Alcídio de Souza Prado (2010). Tem experiência na área de Direito, com ênfase em Direito Privado. E-mail: rodrigordssantos@hotmail.com 
Despite the apparent sedimentation in the doctrine and jurisprudence of the institute of confession in the criminal process, it is certain that, in a more accurate analysis, we can perceive several contradictions and, therefore, we aim to point them out, as well as adopt the best positioning, always with plausible arguments and consistent with the systematics of the current criminal procedure. In the initial chapter, the confession and its nuances are approached, namely, concept, content, legal nature, formal and material requirements, classifications of greater practical importance, the problem of silence as a form of confession in the criminal process Brazilian, and, finally, the main characteristics. In turn, in the next chapter, the probative value of confession in the present day is the object of study. Lastly, in the last chapter, an analysis is made of the main corollaries of the confession in Brazilian criminal proceedings, especially the general mitigating circumstance provided for in article 65, item III, letter " $d$ ", of the Penal Code, and the crime of false self-accusation, established in article 341 of the same legal document.

Keywords: Confession. Proof. Criminal proceedings.

\section{INTRODUÇÃO}

A confissão, consubstanciada na admissão de veracidade de fatos criminosos imputados pela acusação, objeto principal deste artigo, trata-se de um importantíssimo elemento probatório com enorme incidência no processo penal e, por isso, em razão de suas diversas peculiaridades, merece um estudo aprofundado.

De início, no primeiro capítulo, é realizada uma análise extremamente pormenorizada de todas as nuances e peculiaridades da confissão no processo penal. São abordados temas como o conceito, o conteúdo, a natureza jurídica, os requisitos - de ordem formal e de ordem material -, as classificações com maior utilidade prática, a problemática do silêncio como forma de confissão no processo penal brasileiro e as principais características da confissão.

No segundo capítulo, por seu turno, versamos sobre o valor probatório da confissão nos dias atuais, indicando, por meio de entendimentos doutrinários e, sobretudo, jurisprudenciais, qual o posicionamento prevalente.

No terceiro e derradeiro capítulo, cuidamos, finalmente, de apontar e abordar a questão teórica e prática dos consectários decorrentes da confissão no processo penal, merecendo destaque a circunstância atenuante genérica e o delito de autoacusação falsa. 


\section{$1.1 \quad$ CONCEITO}

A confissão encontra na doutrina, conforme menciona Enio Luiz Rossetto ${ }^{2}$, divergência quanto à sua definição.

Há quem entenda que a confissão é a declaração ou o reconhecimento da verdade. A essa corrente se filia, por exemplo, Fernando da Costa Tourinho Filho, para o qual a confissão "é o reconhecimento feito pelo imputado da sua própria responsabilidade"3.

Outros, porém, associam a confissão a um testemunho. Nessa esteira, Frederico Marques definiu que a "confissão, sob o aspecto processual, é um testemunho duplamente qualificado: do ponto de vista objetivo, porque recai sobre fatos contrários ao interesse de quem confessa; e do ponto de vista subjetivo, porque provém do próprio réu"4.

Existem, ainda, aqueles que consideram a confissão uma admissão da veracidade dos fatos que são imputados ao acusado.

Data maxima venia, entendemos que a confissão é o elemento de prova pelo qual o sujeito, acusado ou investigado, durante o interrogatório ou mediante termo, reconhece a veracidade de fatos caracterizadores de um ou mais delitos imputados a si, declinando informações pormenorizadas a respeito da forma como ocorreu e de suas circunstâncias, observadas as formalidades e os requisitos legais.

A fim de melhor elucidar essa questão, faz-se mister assinalar o conceito dado pelo insigne doutrinador e desembargador Guilherme de Souza Nucci:

Confessar, no âmbito do processo penal, é admitir contra si, por quem seja suspeito ou acusado de um crime, tendo pleno discernimento, voluntária, expressa e pessoalmente, diante da autoridade competente, em ato solene e público, reduzido a termo, a prática de algum fato criminoso. ${ }^{5}$

\footnotetext{
${ }^{2}$ ROSSETTO, Enio Luiz. A confissão no processo penal. 1 ed. São Paulo: Atlas, 2001. p. 58-61.

${ }^{3}$ TOURINHO FILHO, Fernando da Costa. Manual de processo penal. 16 ed. São Paulo: 2013. p. 601.

${ }^{4}$ apud ROSSETTO, Enio Luiz. A confissão no processo penal. 1 ed. São Paulo: Atlas, 2001. p. 60.

${ }^{5}$ NUCCI, Guilherme de Souza. O valor da confissão como meio de prova no processo penal. São Paulo: Revista dos Tribunais, 1997. p. 76.
} 
Ademais, consigne-se que, em caso de inexistência de formal acusação, consubstanciada, ao menos, pela instauração de um procedimento investigativo, o ato de admitir o cometimento de um delito não importa confissão, mas sim autoacusação.

\subsection{CONTEÚDO}

O conteúdo da confissão, que deve ser desfavorável àquele que confessa sob pena de desfigurar o instituto em comento, nada mais é que os fatos delituosos imputados pela acusação.

Divergências há, no entanto, no que tange à questão da necessidade ou não de o fato confessado ser renunciável, isto é, disponível.

Embora Adalberto José Q. T. de Camargo Aranha defenda que "o fato confessado deve ser suscetível de renúncia"6, entendemos de modo diferente.

Como é cediço, o direito penal tem por característica a tutela de bens jurídicos indisponíveis e, por isso, aceitar a confissão apenas quanto aos direitos disponíveis significa negar a existência do instituto no âmbito criminal. Além do mais, ressalte-se que apenas os direitos são classificados em disponíveis ou não, posto que fatos são fatos, sem qualquer distinção.

\section{$1.3 \quad$ NATUREZA JURÍDICA}

Trata-se de um meio de prova, funcionando como instrumento de convencimento utilizado pelo magistrado.

Há, todavia, entendimentos diversos.

Enquanto Vicente Greco Filho entende que a confissão "é a própria prova, consistente no reconhecimento da autoria por parte do acusado", para Gustavo Henrique Righi Ivahy Badaró e Márcio Dinamarco a confissão é "o resultado, eventual, do interrogatório", acrescen-

\footnotetext{
${ }^{6}$ ARANHA, Adalberto José Q. T. de Camargo. Da prova no processo penal. 7 ed. São Paulo: Saraiva, 2006. p. 115.

${ }^{7}$ GRECO FILHO, Vicente. Manual de processo penal. 9 ed. São Paulo: Saraiva, 2012. p. 184.
} 
tando, além disso, que "neste caso, o meio de prova [...] será o próprio interrogatório"8.

\section{$1.4 \quad$ REQUISITOS}

É de extrema importância, antes de valorar a confissão de acordo com o caso concreto, verificar a existência de seus requisitos imprescindíveis.

Como bem asseverado por Guilherme de Souza Nucci, "não é qualquer declaração do réu, admitindo sua culpa, que pode ser reputada válida, constituindo meio de prova utilizado pelo juiz para formar seu convencimento"s.

Destarte, para a consecução de uma confissão regular, devem incidir concomitantemente os requisitos que se analisará a seguir.

\subsubsection{REQUISITOS DE ORDEM FORMAL}

São requisitos de ordem formal ou extrínsecos, isto é, de natureza procedimental, que concedem validez à confissão:

Ser expressa: A confissão deve ser explícita e reduzida a termo, a fim de que conste nos autos do processo. É sabido, ademais, que, no processo penal, a confissão ficta ou presumida é inadmitida.

Ser feita perante a autoridade competente: A confissão, quando judicial, deverá ser feita perante o juiz competente do processo, enquanto que a confissão extrajudicial deverá ser feita perante outra autoridade competente, normalmente o Delegado de Polícia responsável pelas investigações preliminares, não se olvidando dos casos de investigações procedidas pelos membros do Ministério Público. Não configura confissão, porém, a admissão da veracidade dos fatos delituosos imputados pela acusação, quando feita informalmente a um policial militar ou outra pessoa qualquer. Nesse último caso, poderá o ouvinte da "confissão", se

\footnotetext{
${ }^{8}$ BADARÓ, Gustavo Henrique Righi Ivaty; DINAMARCO, Márcio. Direito processual penal: tomo I. 2 ed. Rio de Janeiro: Elsevier, 2008. p. 238.

${ }^{9}$ NUCCI, Guilherme de Souza. O valor da confissão como meio de prova no processo penal. São Paulo: Revista dos Tribunais, 1997. p. 149.
} 
arrolado como testemunha, declinar as informações descobertas, que valerão a título de prova testemunhal.

Ser realizada pessoalmente: Não é admissível a confissão realizada por outrem que não seja aquele que irá admitir a veracidade dos fatos delituosos imputados a si. Da mesma forma, não é aceitável a confissão feita pelo defensor do acusado, por exemplo, ainda que esteja portando procuração com poderes especiais. Assim, a confissão deve ser um ato exclusivamente pessoal, feita por quem tenha, de fato, algo a confessar, sob pena de macular este meio de prova de incertezas.

Ser feita por quem tenha higidez mental e capacidade jurídica: A confissão deve ser produzida por alguém juridicamente capaz e em sã consciência. Não se pode admitir a confissão realizada por alguém incapaz e, sobretudo, com enfermidade mental, porquanto tais pessoas não possuem a capacidade de discernimento, trazendo grande risco de existência de conteúdos inverídicos. Em conformidade com o entendimento de Renato Marcão, porém, é apenas inválida a confissão do absolutamente incapaz, porquanto "o relativamente incapaz pode confessar validamente, assim como o adolescente infrator poderá fazê-lo nos procedimentos que tramitam perante a Vara da Infância e da Juventude"10.

Ser livre e voluntária: Aqui, talvez, repouse o motivo de maior divergência. É pacífico que a confissão deve ser produto da liberdade do confitente, alheia de qualquer erro, coação ou tortura, sob pena de ser desentranhada do processo, nos exatos termos do artigo 157 do Código de Processo Penal. Diferentemente, contudo, quanto à necessidade de espontaneidade do acusado ou investigado, a doutrina diverge. Exemplificando, defende Guilherme de Souza Nucci que "não necessita a confissão ser espontânea, vale dizer, sincera e demonstrativa do arrependimento do confitente"11, enquanto, em contrapartida, para Manzini, "no processo penal [...] pode-se considerar, para efeito de prova, somente a confissão espontânea" ${ }^{, 12}$.

\subsubsection{REQUISITOS DE ORDEM MATERIAL}

\footnotetext{
${ }^{10}$ MARCÃO, Renato. Curso de processo penal. São Paulo: Saraiva, 2014. p. 397.

${ }^{11}$ NUCCI, Guilherme de Souza. O valor da confissão como meio de prova no processo penal. São Paulo: Revista dos Tribunais, 1997. p. 154.

${ }^{12}$ apud ROSSETTO, Enio Luiz. A confissão no processo penal. 1 ed. São Paulo: Atlas, 2001. p. 113.
} 
Além dos pressupostos expostos acima, que conferem validade à confissão, necessário se faz para o seu devido aproveitamento como meio de prova a observância de outros requisitos.

São requisitos de ordem material ou intrínsecos ao próprio ato de confessar e que, portanto, lhe conferem credibilidade:

Verossimilhança: A confissão deve ser verossímil, ou seja, a admissão da veracidade dos fatos imputados contra o confitente deve ser ao menos provável. Como bem sustenta Enio Luiz Rossetto, "a verossimilhança é a probabilidade de o fato ter ocorrido como confessado"13. Assim, a título de exemplo, não se nota a probabilidade necessária quando um acusado, do sexo masculino, assume a prática de um autoaborto.

Clareza: A confissão, conforme assinalam Nestor Távora e Rosmar Rodrigues Alencar, deve estar "despida de ambigüidades, contradições ou elementos que possam dificultar o entendimento do ocorrido ou a real vontade do confidente" ${ }^{\text {14 }}$. A ausência de clareza, portanto, torna a confissão incompreensível e, nos dizeres de Guilherme de Souza Nucci, "o juiz não deve interpretar o sentido das palavras [...] pois poderá sobrepor-se à própria vontade do confitente" 15 .

Certeza: A confissão deve estar relacionada com aquilo que é de conhecimento do acusado ou indiciado, porquanto vivenciara isso, não se admitindo que suas declarações tenham por base aquilo que "ouviu dizer". Também, consigne-se, não existe confissão presumida ou condicionada. Além disso, deve-se ressaltar que este requisito está intimamente ligado com a convicção provocada pela confissão ao magistrado.

Persistência e uniformidade: Quanto menor as disparidades apresentadas entre as inúmeras vezes que confessar, maior segurança transmitirá o acusado ou indiciado com as suas declarações. Mais uma vez valendo-me dos escritos de Guilherme de Souza Nucci, o insigne doutrinador preleciona que "a verdade não comporta grande divergência ou distorção, apesar de existirem lapsos de memória" ${ }^{16}$. Assim, ressalvando, face ao sistema da persuasão racional, os casos de retratação da

\footnotetext{
${ }^{13}$ ROSSETTO, Enio Luiz. A confissão no processo penal. 1 ed. São Paulo: Atlas, 2001. p. 108.

${ }^{14}$ TÁVORA, Nestor; ALENCAR, Rosmar Rodrigues. Curso de direito processual penal. 6 ed. Salvador: Juspodivm, 2011. p. 415.

${ }^{15}$ NUCCI, Guilherme de Souza. O valor da confissão como meio de prova no processo penal. São Paulo: Revista dos Tribunais, 1997. p. 150.

${ }^{16}$ NUCCI, Guilherme de Souza. O valor da confissão como meio de prova no processo penal. São Paulo: Revista dos Tribunais, 1997. p. 151.
} 
confissão feita pelo agente confitente e utilizada pelo magistrado em seu convencimento, quanto menores forem as divergências, maior será o valor atribuído à confissão.

Coerência: A confissão nos dias atuais, como é cediço, não tem valor probatório absoluto, por isso, faz-se necessário que seja corroborada pelas demais provas amealhadas nos autos. Não se concebe, por exemplo, que o acusado confesse falsamente a prática de um furto, quando a própria vítima e as testemunhas arroladas declarem em sentido diverso. Contudo, devemos registrar aqui que, em virtude do sistema da persuasão racional, não se pode decidir de acordo com a quantidade de provas, mas sim pela verdade que transmitem.

Conteúdo relacionado ao confitente: Conforme se viu nessa monografia, confessar é, em síntese, admitir a veracidade dos fatos delituosos a si imputados. Desse modo, o ato de confessar algum fato relacionado a outrem não configura o meio de prova em tela. Pode o acusado ou indiciado, no entanto, ao confessar fato relacionado a si próprio, indicar a participação de terceiros, caso em que estaremos diante de uma delação, o que se verá no capítulo seguinte. Ademais, não se olvide que, além de tudo, a confissão deve ter por conteúdo fato desfavorável ao confitente, uma vez que não se permite a confissão em benefício próprio, malgrado em certos casos represente, de forma indireta, vantagem àquele que confessou.

\subsection{CLASSIFICAÇÕES DA CONFISSÃO}

A doutrina acostumou-se classificar a confissão de acordo com vários critérios, a fim de melhor estudá-la e aplicá-la no caso concreto.

Seguindo, então, essa tradição doutrinária, analisaremos a seguir a confissão tendo em vista quatro critérios distintos.

\subsubsection{QUANTO AO LOCAL EM QUE É OBTIDA}

Deveras a mais importante das classificações realizadas pela doutrina, vez que apresenta enorme utilidade prática, quanto ao local em que é obtida, a confissão pode ser extrajudicial ou judicial. 
Embora Adalberto José Q. T. de Camargo Aranha ${ }^{17}$ aponte ser de difícil conceituação, é certo que a confissão extrajudicial nada mais é que aquela obtida fora do juízo, ou seja, durante um inquérito policial, um procedimento administrativo ou uma sindicância, por exemplo. Sua maior característica é a ausência dos princípios constitucionais do contraditório e da ampla defesa, o que inviabiliza, nos termos do artigo 155 do Código de Processo Penal, sua utilização exclusiva para fins condenatórios.

Consigne-se, ademais, ser imprescindível, além da observância dos demais requisitos de uma confissão normal, tal qual a realizada em juízo, que a confissão classificada como extrajudicial seja escrita, isto é, reduzida a termo, sob pena de não valer como meio de prova.

Questão de controvérsia doutrinária e jurisprudencial já debatida nesta monografia refere-se à possibilidade de utilização da confissão colhida extrajudicialmente na fundamentação do magistrado.

Objetivando apenas ratificar o posicionamento que se adota, convém colacionar a colenda jurisprudência: "A confissão vale não pelo local em que é prestada, mas pela força de convencimento que nela se contém, pelo que não pode ser desprezada a extrajudicial, quando se harmoniza com a prova colhida na instrução"18.

De outra banda, a confissão judicial é aquela que, diante de uma formal acusação, é obtida durante o próprio processo, perante autoridade judiciária, através do interrogatório ou mediante termo juntado nos autos, conforme explica o artigo 199 do Código de Processo Penal. Nessa espécie, obviamente, vigoram os princípios do contraditório e da ampla defesa. Além disso, por ser imprescindível a presença de defesa técnica durante a sua realização, a confissão colhida em sede judicial tem o condão de embasar uma decisão do magistrado, desde que cotejada com os demais elementos probatórios colhidos, consoante o disposto no artigo 197 do Código de Processo Penal.

A confissão judicial apresenta, ainda, uma subclassificação: será considerada própria quando feita perante a autoridade judiciária competente; enquanto que será imprópria nos casos em que realizada perante juiz incompetente para o processo.

\footnotetext{
${ }^{17}$ ARANHA, Adalberto José Q. T. de Camargo. Da prova no processo penal. 7 ed. São Paulo: Saraiva, 2006. p. 119.

${ }^{18}$ TACrim, Rel. Bento Mascarenhas, RT. 729:583.
} 
Acerca da denominada confissão judicial imprópria, exemplificam Nestor Távora e Rosmar Rodrigues Alencar: "É possível que seja realizada perante autoridade incompetente para o julgamento do processo, como na hipótese de carta precatória"19.

Desse modo, em que pese à inexistência de hierarquia entre os elementos de prova, é patente que a confissão judicial tem maior valor que a colhida em sede inquisitorial, visto que aquela tem o condão de embasar um juízo condenatório.

\subsubsection{QUANTO À PLENITUDE}

Quanto à plenitude, a confissão classifica-se em plena e semiplena.

É plena a confissão quando todas as imputações forem confessadas, enquanto que será semiplena ou parcial nos casos em que o confitente reconheça a veracidade de apenas alguns fatos, não admitindo a veracidade de outros.

\subsubsection{QUANTO AO CONTEÚDO}

No que se refere ao conteúdo, a confissão pode ser classificada em simples, complexa e qualificada.

É simples a confissão que se limitar na admissão da veracidade dos fatos delituosos imputados pela acusação, sem qualquer outra alegação.

Por sua vez, será considerada complexa a confissão que, do mesmo modo, se restringe na simples admissão de veracidade, contudo de inúmeros e diversos fatos.

Note que, nas duas espécies supramencionadas, o acusado ou indiciado admite os fatos a ele imputados, sem apresentar qualquer objeção à sua responsabilidade penal, diferenciando-se ambas apenas quanto à quantidade dos fatos confessados.

Há ainda a denominada confissão qualificada, que se caracteriza pela admissão da veracidade dos fatos imputados em conjunto com a

\footnotetext{
${ }^{19}$ TÁVORA, Nestor; ALENCAR, Rosmar Rodrigues. Curso de direito processual penal. 6 ed. Salvador: Juspodivm, 2011. p. 414.
} 
alegação de alguma circunstância que afaste a consumação do crime ou isente o confitente da pena, tais como causa excludente de ilicitude, de culpabilidade ou eximente de responsabilidade penal.

Também configura a confissão qualificada quando o confitente limita-se a confessar em parte os fatos delituosos, deixando de admitir a veracidade de outra parte que lhe seria mais desfavorável.

Enio Luiz Rossetto dá exemplos desta última espécie:

O acusado pode confessar o crime, mas negar um elemento do fato típico; v.g., admite o homicídio, mas nega a qualificadora de tê-lo cometido por motivo fútil (art. 121, §2. $\left.{ }^{\circ}, \mathrm{II}, \mathrm{CP}\right)$. Ou confessa ter matado; porém, por ter agido em legítima defesa, nega antijuridicidade. Assim, o acusado admite em parte a imputação, confessando a prática do delito, mas apontando motivos ou circunstâncias que o justificariam ou o atenuariam; está-se diante da denominada confissão qualificada. ${ }^{20}$

Prosseguindo, discute-se na doutrina se esta espécie rotulada como qualificada deveria ser considerada, de fato, uma confissão.

Alegam alguns que a forma qualificada, por conter partes que beneficiam o confitente, não poderia ser considerada uma confissão propriamente dita, uma vez que uma de suas premissas é de que seja contrária ao agente que confessou.

Dessa forma entende Adalberto José Q. T. de Camargo Aranha, ao dispor que "a confissão qualificada não é verdadeiramente uma confissão" 21 .

Não nos parece, porém, o melhor entendimento. Isso porque, conforme a característica da divisibilidade da confissão, o magistrado pode valer-se apenas da parte em que o confitente assume a ocorrência de fatos desfavoráveis a si.

Ademais, fora recentemente assentado pelo Superior Tribunal de Justiça (STJ) que, em casos de confissão qualificada, admite-se a inci-

\footnotetext{
${ }^{20}$ ROSSETTO, Enio Luiz. A confissão no processo penal. 1 ed. São Paulo: Atlas, 2001. p. 96.

${ }^{21}$ ARANHA, Adalberto José Q. T. de Camargo. Da prova no processo penal. 7 ed. São Paulo: Saraiva, 2006. p. 115.
} 
dência da circunstância atenuante genérica prevista no artigo 65, inciso III, alínea "d", do Código Penal.

Explicitando o entendimento do aludido egrégio tribunal de que a confissão qualificada deve ser tratada como um elemento de prova, dispõe a colenda jurisprudência:

AGRAVO REGIMENTAL NO RECURSO ESPECIAL. CRIMES CONTRA A PESSOA. HOMICÍDIO DOLOSO TENTADO. CONFISSÃO QUALIFICADA. INCIDÊNCIA DA ATENUANTE PREVISTA NO ART. 65, III, DO CÓDIGO PENAL. POSSIBILIDADE. RECENTE POSICIONAMENTO DO STJ. AGRAVO REGIMENTAL NÃO PROVIDO. 1. Recente jurisprudência desta Corte passou a adotar o posicionamento no sentido de que, mesmo ficando configurada a confissão na modalidade qualificada, é cabível o reconhecimento da incidência da atenuante da confissão prevista no art. 65, III, d, do Código Penal. 2. Agravo regimental não provido. ${ }^{22}$

Portanto, é patente que, embora apresente a peculiaridade de possuir conteúdo também favorável ao réu, a confissão qualificada, quando utilizada na parte que é contrária aos interesses daquele que a realizou, deve sim ser considerada um meio de prova e gerar todas as consequências que da confissão decorrem.

\subsubsection{QUANTO À FORMA DE EXTERIORIZAÇÃO}

Extremamente relevante a classificação da confissão quanto à forma como é exteriorizada, dividindo-se basicamente em explícita ou direta e implícita ou indireta.

Por confissão explícita ou direta entende-se aquela em que o confitente, por meio de declaração escrita ou verbal reduzida a termo, reconhece os fatos criminosos imputados pela parte acusadora. Trata-se da confissão propriamente dita, uma vez que cumpre o requisito de ser

\footnotetext{
${ }^{22}$ Superior Tribunal de Justiça. AgRg no REsp: 1384067 SE 2013/0168525-0, Relator: Ministro MOURA RIBEIRO, Data de Julgamento: 06/02/2014, T5 - QUINTA TURMA, Data de Publicação: DJe 12/02/2014.
} 
expressa, ou seja, é exteriorizada por uma ação específica para o fim de confessar, não havendo a necessidade de presunções.

Por sua vez, a confissão implícita ou indireta subdivide-se em outras duas: a ficta ou tácita e a presumida.

A confissão presumida decorre de atos praticados pelo acusado ou indiciado que fazem presumir a sua culpa. Exemplificando, configura essa espécie de confissão a reparação do dano ou restituição da coisa furtada, requisito do arrependimento posterior.

Essa subespécie, conforme ensina Renato Marcão, "funciona como simples indício, sem força de confissão propriamente" 23 , visto que, para caracterizá-la como meio de prova, necessário se faz a observância de todos os requisitos imprescindíveis.

Já a confissão tácita ou ficta é aquela decorrente de uma atitude omissiva do réu ou indiciado. Assim, são exemplos dessa subespécie, a falta de comparecimento na audiência designada, que acarreta a revelia, com efeitos diferentes do processo civil, isto é, apenas a não intimação do acusado para a realização dos atos posteriores, ou o silêncio do réu ou indiciado em seu interrogatório, garantido pelo Pacto de San José da Costa Rica e pela Constituição Federal de 1988 , em seu artigo $5^{\circ}$, inciso LXIII.

Segundo expõe Vicente Greco Filho, "inexiste no processo penal confissão ficta ou presumida, quer decorrente do silêncio, quer decorrente da revelia. Ambos, silêncio ou revelia, não podem ser dados como confissão" 24 .

Arrematando, determinam Nestor Távora e Rosmar Rodrigues Alencar que "[...] pela presunção de inocência [...] a confissão tácita não tem aplicação na esfera criminal"25.

Assim sendo, é inadmissível a confissão ficta, não se permitindo que o magistrado faça presunções de culpa, impondo, em casos tais, soluções absolutórias.

\footnotetext{
${ }^{23}$ MARCÃO, Renato. Curso de processo penal. São Paulo: Saraiva, 2014. p. 397.

${ }^{24}$ GRECO FILHO, Vicente. Manual de processo penal. 9 ed. São Paulo: Saraiva, 2012. p. 185.

${ }^{25}$ TÁVORA, Nestor; ALENCAR, Rosmar Rodrigues. Curso de direito processual penal. 6 ed. Salvador: Juspodivm, 2011. p. 414.
} 


\subsection{A PROBLEMÁTICA DO SILÊNCIO COMO FORMA DE CONFISSÃO NO PROCESSO PENAL BRASILEIRO}

Malgrado a norma estabelecida pelo artigo 198 do Código de Processo Penal disponha que "O silêncio do acusado não importará confissão, mas poderá constituir elemento para a formação do convencimento do juiz" 26 , a nossa Magna Carta instituiu expressamente o direito ao silêncio, determinando, em seu artigo $5 .^{\circ}$, inciso LXIII, que "o preso será informado de seus direitos, entre os quais o de permanecer calado [...]"27, devendo-se concluir, assim, que a Constituição Federal do Brasil de 1988 não recepcionou a norma infraconstitucional que possibilitava a utilização do silêncio como meio de convencimento.

Ademais, não se olvide da esclarecedora regra presente no artigo 186, parágrafo único, do Código de Processo Penal, com redação dada pela Lei n. 10.792/2003, determinando que "o silêncio, que não importará em confissão, não poderá ser interpretado em prejuízo da defesa" ${ }^{28}$, o que serve para corroborar ainda mais este entendimento.

Destarte, consoante Aury Lopes Júnior

O art. 198 do CPP deve ser lido à luz do direito constitucional de silêncio e em conformidade com a estrutura do devido processo. Assim, o silêncio não importará confissão, e tampouco pode ser (des)valorado pelo juiz. Ou seja, é substancialmente inconstitucional a última parte do referido artigo, quando afirma que o silêncio do acusado 'poderá constituir elemento para a formação do convencimento do juiz. Não, isso não sobrevive a uma filtragem constitucional. Assim, o silêncio não pode prejudicar, em nenhuma hipótese, o réu, e tampouco pode ser utilizado como elemento para o convencimento do juiz. ${ }^{29}$

Dessa maneira, tendo em vista ainda o consagrado princípio do "nemo tenetur se detegere", além de inconstitucional, a norma presente

26 Código de Processo Penal. Brasília: Senado, 1941.

${ }^{27}$ BRASIL, Constituição (1988). Constituição da República Federativa do Brasil. Brasília: Senado, 1988.

${ }^{28}$ _. Código de Processo Penal. Brasília: Senado, 1941.

${ }^{29}$ LOPES JUNIOR, Aury. Direito processual penal. 11 ed. São Paulo: Saraiva, 2014. p. 471. 
no artigo 198 do Código de Processo Penal foi tacitamente revogada pelo disposto no artigo 186, caput, do aludido diploma processual penal, e, portanto, o silêncio do acusado ou investigado em qualquer fase da persecução penal nada representa, não havendo, em hipótese alguma, que se fazer presunções de culpa.

\subsection{CARACTERÍSTICAS DA CONFISSÃO}

A confissão, como meio de prova, possui duas características marcantes, mencionadas, inclusive, no ordenamento processual penal brasileiro.

Nos termos do artigo 200 do Código de Processo Penal, “a confissão será divisível e retratável [...]"30.

Diante disso, portanto, a confissão se caracteriza por sua retratatibilidade e divisibilidade

\subsubsection{RETRATABILIDADE}

A retratação da confissão consiste no ato de desdizer aquilo que já fora dito; de negar aquilo que outrora fora admitido como verdadeiro.

Reforçando, segundo Vicente Greco Filho "a retratabilidade significa que, a qualquer tempo, pode o acusado retirar a confissão anteriormente feita" 31 .

Acerca da retratabilidade da confissão no processo penal existem duas posições distintas.

De um lado, posicionam-se os que consideram a confissão, por ser proveniente de uma manifestação de vontade do acusado, um ato jurídico e, por esse motivo, apenas se permite a sua retratação nos casos de vício decorrente de erro, dolo ou coação. Acrescentam, ainda, os adeptos desta posição que a confissão quando prestada por ato sem qualquer vício e por pessoa inteiramente capaz não pode ser desmentida, ou seja, retratada.

\footnotetext{
30 Código de Processo Penal Penal. Brasília: Senado, 1941.

${ }^{31}$ GRECO FILHO, Vicente. Manual de processo penal. 9 ed. São Paulo: Saraiva, 2012. p. 185.
} 
Adotando este posicionamento, Adalberto José Q. T. de Camargo Aranha disciplina que "só valerá a retratação se gerada por vício de inteligência (erro ou dolo) ou de vontade (coação)" "32.

De outro lado, estão presentes os que consideram que, justamente pelo fato de a confissão decorrer de um ato livre e voluntário do acusado, a sua retratação pode se dar em qualquer hipótese, não necessitando cumprir qualquer requisito.

Atualmente, esse assunto já se encontra sedimentado, sendo o entendimento majoritário da doutrina e da jurisprudência no sentido de que vale a retratação da confissão, independentemente da incidência de algum vício que macule a vontade do confitente.

Dessa maneira, o magistrado não pode indeferir o desejo de retratação do acusado, devendo, inclusive, se necessário, designar data para novo interrogatório, consoante o disposto no artigo 196 do Código de Processo Penal.

Entretanto, em virtude do sistema de valoração probatória que vigora no ordenamento processual penal, qual seja o do livre convencimento motivado, não fica o magistrado vinculado à retratação da confissão feita pelo acusado.

Assim, é absolutamente possível que, não se convencendo com a retratação, o magistrado decida em sentido oposto, levando em consideração, inclusive, a confissão retratada como meio de convencimento, obviamente corroborada por outros elementos probatórios constantes no processo.

Com mais clareza, são as palavras de Enio Luiz Rossetto:

Vale notar que a confissão e a retratação devem ser apreciadas conjuntamente. Válida a confissão obtida de maneira espontânea e livre e que, se comparada com outras provas, mostra-se sincera; por outro lado, é carente de valor a retratação que não tem amparo noutras provas. ${ }^{33}$

Corroborando, a jurisprudência explicita a retratabilidade da confissão no caso concreto: "A confissão pode ser retratada em juízo, mas

\footnotetext{
${ }^{32}$ ARANHA, Adalberto José Q. T. de Camargo. Da prova no processo penal. 7 ed. São Paulo: Saraiva, 2006. p. 120.

${ }^{33}$ ROSSETTO, Enio Luiz. A confissão no processo penal. 1 ed. São Paulo: Atlas, 2001. p. 75.
} 
para que seja aceita essa retratação é mister que, além de verossímil, encontre algum amparo ainda que em elementos indiciários ou circunstanciais dos autos." 34

No mesmo sentido:

A retratação da confissão não produz efeitos por si mesma. Cumpre ser acompanhada de provas elidentes da confissão. Mister se faz que o confitente explique, satisfatoriamente, os seus motivos e forneça, também, as provas destes. ${ }^{35}$

Isto posto, ante a evolução do instituto da confissão e a liberdade de convencimento do magistrado, é amplamente cabível a retratação da confissão, cabendo ao julgador, no cotejo de todo o acervo probatório, decidir de maneira fundamentada.

\subsubsection{DIVISIBILIDADE}

A divisibilidade ou cindibilidade consiste na possibilidade de o magistrado desmembrar o teor da confissão, utilizando uma parte, enquanto refuta outra.

Como bem observado por Gustavo Henrique Righi Ivahy Badaró e Márcio Dinamarco ${ }^{36}$, a divisibilidade possui intima ligação com a confissão qualificada, que, conforme vimos, é aquela em que o confitente admite a veracidade dos fatos a ele imputados, ao mesmo tempo em que alega alguma causa capaz de eximir sua responsabilidade penal.

Para o doutrinador Adalberto José Q. T. de Camargo Aranha ${ }^{37}$, no entanto, existem duas hipóteses em que não se admite a divisão da confissão. São elas: quando o acusado acrescenta ao fato a ele imputado algum outro que negue a acusação e nos casos de confissão qualificada.

\footnotetext{
${ }^{34}$ Ap. 4.072, TACrimSP, Rel. Toledo Assumpção, RT, 393:343.

${ }^{35}$ Ap. 60.706, TACrimSP, Rel. Castro Garms.

${ }^{36}$ BADARÓ, Gustavo Henrique Righi Ivaty; DINAMARCO, Márcio. Direito processual penal: tomo I. 2 ed. Rio de Janeiro: Elsevier, 2008. p. 239.

${ }^{37}$ ARANHA, Adalberto José Q. T. de Camargo. Da prova no processo penal. 7 ed. São Paulo: Saraiva, 2006. p. 120-121.
} 
Ainda conforme o aludido doutrinador Adalberto José Q. T. de Camargo Aranha, nestes casos, "se dividirmos uma afirmativa, dando validade a uma parte e renegando a outra, poderemos fugir da real intenção do declarante, afastando a verdade. A cisão poderá importar na admissão do que não se quis afirmar" 38 .

De outro modo, porém, é o entendimento que vigora nos dias atuais. A divisibilidade da confissão é uma consequência natural do moderno sistema de valoração probatória denominado de persuasão racional ou livre convencimento motivado, visto que ao magistrado é dada toda a liberdade para apreciar os elementos de prova constantes no processo e utilizar para a sua decisão justificada as partes que lhe parecerem verídica.

A título de exemplo, Renato Marcão aduz que

Se o acusado confessar a autoria de um furto e alegar, na mesma ocasião, que agiu em estado de necessidade, finda a instrução, ao cotejar as provas o juiz poderá concluir que a confissão está em consonância com outras provas colhidas, quanto à autoria, e que a alegada excludente não restou provada. ${ }^{39}$

Sendo assim, é perfeitamente possível que o magistrado leve em conta para o seu convencimento a parte em que o acusado confesse a veracidade dos fatos imputados pela acusação, porquanto encontra respaldo em outras provas, e, de outro modo, refute a parte em que o mesmo acusado tente eximir a sua responsabilidade penal, não havendo que se falar em fuga da vontade do agente confitente.

Aliás, em consonância com este entendimento, atentemos para o disposto na colenda jurisprudência do egrégio Superior Tribunal de Justiça (STJ):

PENAL E PROCESSUAL PENAL. AGRAVO REGIMENTAL NO AGRAVO EM RECURSO ESPECIAL. FALSIFICAÇÃO DE DOCUMENTO PÚBLICO. REDIMENSIONAMENTO DA PENA. "CONFISSÃO QUALIFICADA" USADA PARA

\footnotetext{
${ }^{38}$ ARANHA, Adalberto José Q. T. de Camargo. Da prova no processo penal. 7 ed. São Paulo: Saraiva, 2006. p. 120.

${ }^{39}$ MARCÃO, Renato. Curso de processo penal. São Paulo: Saraiva, 2014. p. 398.
} 
EMBASAR O DECRETO CONDENATÓRIO. RECONHECIMENTO DA ATENUANTE. ADESÃO AO NOVO ENTENDIMENTO. AGRAVO PROVIDO. 1. Embora não se desconheça o entendimento até então manifestado por esta Corte Superior de Justiça em inúmeros julgados, no sentido de que "A confissão qualificada, na qual o agente agrega à confissão teses defensivas descriminantes ou exculpantes, não tem o condão de ensejar o reconhecimento da atenuante prevista no art. 65, inciso III, alínea d, do Código Penal" (HC 211.667/RJ, Rel. Ministra LAURITA VAZ, QUINTA TURMA, julgado em 18/06/2013, DJe 01/07/2013), após detido reexame do tema, conclui-se de modo diverso. 2. Colhe-se dos autos que a agravante confessou a prática do crime "ainda que evasiva de arrependimento e com possível intenção de eximir-se da culpa". Nesse viés, verifica-se que a confissão serviu para a comprovação da autoria, bem como embasar o decreto condenatório. Em hipóteses tais, o reconhecimento da atenuante se impõe. Vale dizer, se a confissão do agente é um dos fundamentos da condenação, a atenuante prevista no art. 65, inciso III, alínea d, do CP, deve ser aplicada, sendo irrelevante se a confissão foi espontânea ou não, total ou parcial, ou mesmo se houve retratação posterior. 3. Com efeito, tal entendimento deve se estender para as hipóteses da chamada "confissão qualificada". Em outras palavras, a invocação de teses defensivas excludentes ou descriminantes não pode obstar a incidência da atenuante da confissão quando ela é utilizada para embasar o próprio decreto condenatório. 4. A propósito: "É assente neste Tribunal Superior o entendimento de que "a invocação de excludente de ilicitude não obsta a incidência da atenuante da confissão espontânea" (AgRg no AREsp 210.246/SP, Rel. Min. MARIA THEREZA DE ASSIS MOURA, SEXTA TURMA, DJe 01/08/2013). 5. No mesmo sentido: "A invocação de causa excludente de ilicitude não obsta reconhecimento da incidência da atenuante da confissão espontânea. (AgRg no Ag 1242578/SP, Rel. Min. MARCO AURÉLIO BELLIZZE, QUINTA TURMA, DJe 14/11/2012) 6. Agravo regimental provido 
para negar provimento ao Agravo de Instrumento do Ministério Público, mantendo a pena nos exatos termos como fixada pelo Tribunal de piso, ou seja, com a incidência da atenuante da confissão (art. 65, II, d, do Código Penal). ${ }^{40}$

Por fim, entretanto, é forçoso ressaltar que, em conformidade com os ensinamentos de Guilherme de Souza Nucci, é vedado "ao magistrado [...] repartir a confissão em porções estanques, sem sentido e com quebra de contexto. Assim, não se pode dividir frases ou mesmo uma narrativa que possui um contexto único, pois, nesse caso, deturpa-se por completo a ideia exposta pelo interrogado"41.

\section{O VALOR PROBATÓRIO DA CONFISSÃO NOS DIAS ATUAIS}

Se antigamente, em virtude do sistema da prova legal ou tarifada que vigorava no Brasil, a confissão possuía valor absoluto, maior que qualquer outro elemento de prova, sendo considerada, inclusive, a "rainha das provas", nos dias atuais, a realidade é completamente distinta.

Com o advento do sistema do livre convencimento motivado, adotado pelo artigo 93, IX, da Constituição Federal de 1988, e pelo artigo 155, caput, do Código de Processo Penal, a confissão deixou de ser considerada prova plena da culpabilidade do acusado e passou a ser relativizada consoante o caso concreto, a fim de que valha para o convencimento do magistrado na mesma medida que os demais elementos de prova.

A própria Exposição de Motivos do CPP, em seu item VII, diz expressamente que a " [....] confissão do acusado não constitui, fatalmente, prova plena de sua culpabilidade. Todas as provas são relativas. Nenhuma delas terá, ex vi legis, valor decisivo, ou necessariamente maior prestígio que outra" 42 .

\footnotetext{
${ }^{40}$ Superior Tribunal de Justiça. AgRg no Ag: 1410103 CE 2011/0129539-2, Relator: Ministro JORGE MUSSI, Data de Julgamento: 07/11/2013, T5 - QUINTA TURMA, Data de Publicação: DJe 21/11/2013

${ }^{41}$ NUCCI, Guilherme de Souza. Manual de processo penal e execução penal. 11 ed. Rio de Janeiro: Forense, 2014. p. 574.

42

Exposição de Motivos do Código de Processo Penal de 1941. DOU 13/10/1941.
} 
Com efeito, como preceitua o artigo 197 do Código de Processo Penal, "o valor da confissão se aferirá pelos critérios adotados para os outros elementos de prova, e para a sua apreciação o juiz deverá confrontá-la com as demais provas do processo, verificando se entre ela e estas existe compatibilidade ou concordância"43.

Assim, o magistrado deverá, para lhe emprestar o valor probatório merecido, cotejar a confissão obtida com os demais elementos de prova constantes nos autos, a fim de verificar, conforme o seu livre convencimento devidamente justificado, a maior ou menor incidência de seus requisitos que lhe conferem a credibilidade.

Obviamente que, em virtude da incidência ou não do contraditório e da ampla defesa, princípios constitucionais previstos no artigo $5 .^{\circ}$, inciso LV, da Constituição Federal de 1988, a confissão, em que pese à contemporânea ausência de hierarquia entre as provas, deverá ser apreciada de modo distinto, conforme seja colhida judicial ou extrajudicialmente.

Quanto à confissão obtida judicialmente, sob o crivo do contraditório e da ampla defesa, existe divergência a respeito da possibilidade de embasar, sem qualquer outro elemento de prova, um decreto condenatório.

De um lado repousa entendimento no sentido de que a confissão pode amparar uma decisão condenatória, ainda que seja o único elemento probatório incriminador.

Paulo:

Nesse sentido, já decidiu o egrégio Tribunal de Justiça de São

Processo Penal. Prova. Confissão judicial. Eficácia probatória. A confissão judicial tem um valor absoluto, servindo como base condenatória ainda que seja o único elemento incriminador. ${ }^{44}$

De outro lado, está o entendimento para o qual a confissão somente pode sustentar uma condenação, se confirmada por outros elementos de prova.

${ }_{44}$ Tribunal de Justiça do Estado de São Paulo. APL: 30029971420138260562 SP $3002997-$ 14.2013.8.26.0562, Relator: Souza Nery, Data de Julgamento: 06/08/2015, 9a Câmara de Direito Criminal, Data de Publicação: 10/08/2015. 
Defendendo este entendimento, Gustavo Henrique Righi Ivahy Badaró e Márcio Dinamarco mencionam que "a interpretação conjunta dos artigos 197 e 200 do CPP leva à conclusão de que a confissão isolada não é suficiente para a condenação, pois ela sempre deve ser valorada com os demais elementos de prova" 45 .

No mesmo diapasão, Norberto Cláudio Pâncaro Avena preceitua que "[...] não tem a confissão força probatória absoluta, havendo a necessidade, para o fim de fundamentar sentença condenatória, de que seja confrontada e confirmada pelas demais provas existente nos autos" ${ }^{\prime 4}$.

Ainda, nesse sentido, é o que dispõe a colenda jurisprudência:

HABEAS CORPUS. ESTATUTO DA CRIANÇA E DO ADOLESCENTE. ATO INFRACIONAL EQUIPARADO A ROUBO. CONFISSÃO. DESISTÊNCIA DE PRODUÇÃO DE OUTRAS PROVAS. CERCEAMENTO DE DEFESA. CONSTRANGIMENTO ILEGAL EVIDENCIADO. O direito ao contraditório e à ampla defesa são consagrados no texto constitucional. A confissão da prática de ato infracional não exime o juiz de colher outras provas. Seja qual for a sua clareza, não se pode jamais considerá-la exclusivamente para efeito de uma condenação, sem confrontá-la com outros elementos, que possam confirmá-la ou contraditá-la. O direito de defesa é irrenunciável, não podendo dele dispor o acusado, seu advogado, o Ministério Público, pois o Estado/Juiz deve sempre buscar a verdade dos fatos. Ordem CONCEDIDA tão-só para anular a sentença hostilizada, possibilitando que outra seja proferida em seu lugar, com observância do devido processo legal e seus consectários. ${ }^{47}$

Acerca disso, preferimos adotar a segunda posição. Malgrado defendamos que a prova vale pela sua qualidade, isto é, pela verdade que transmite, e não por sua quantidade, a confissão não ratificada por outros

\footnotetext{
${ }^{45}$ BADARÓ, Gustavo Henrique Righi Ivaty; DINAMARCO, Márcio. Direito processual penal: tomo I. 2 ed. Rio de Janeiro: Elsevier, 2008. p. 240.

${ }^{46}$ AVENA, Norberto. Processo penal: esquematizado. 6 ed. São Paulo: Método, 2014. p. 532.

${ }^{47}$ Superior Tribunal de Justiça. HC: 50304 RJ 2005/0195129-6, Relator: Ministro PAULO MEDINA, Data de Julgamento: 17/08/2006, T6 - SEXTA TURMA, Data de Publicação: DJ 25.09.2006 p. 313.
} 
elementos não representa a credibilidade necessária para a sustentação de uma decisão condenatória, mesmo porque estarão ausentes alguns dos requisitos que the conferem tal mestria.

Ademais, segundo preleciona Edilson Mougenot Bonfim, "não raro a confissão é prestada de maneira fraudulenta, não podendo o julgador ficar adstrito ao seu conteúdo para proferir o julgamento" 48 .

\section{OS PRINCIPAIS COROLÁRIOS DA CONFISSÃO NO PROCESSO PENAL BRASILEIRO}

\subsection{A CONFISSÃO COMO CIRCUNSTÂNCIA ATENUANTE GENÉRICA}

Diferentemente do que ocorria antes da reforma trazida pela Lei n. 7.209/1984, quando, para que a confissão fosse utilizada como circunstância atenuante genérica, fazia-se mister, além da espontaneidade, que estivesse comprovado o estado de arrependimento bem como a inexistência de provas quanto ao fato confessado, hoje em dia, os requisitos são mais brandos e fáceis de serem cumpridos.

Consoante dispõe o artigo 65, inciso III, alínea "d", do Código Penal, incidirá a circunstância atenuante genérica quando o agente houver "confessado espontaneamente, perante a autoridade, a autoria do crime" 49 .

Anote-se que, apesar da expressa menção da espontaneidade como pressuposto para o reconhecimento da confissão como atenuante da pena, é fato que, na verdade, o que se requer é que a confissão seja voluntária, isto é, alheia a qualquer intervenção de terceiro que a macule.

O Superior Tribunal de Justiça (STJ) já sedimentou seu entendimento:

\footnotetext{
${ }^{48}$ BONFIM, Edilson Mougenot. Curso de processo penal. 9 ed. São Paulo: Saraiva, 2014. p. 421. 
HABEAS CORPUS. INCIDÊNCIA DA ATENUANTE PREVISTA NO ART. 65, III, "D", DO CÓDIGO PENAL. REQUISITOS MERAMENTE OBJETIVOS. DISTINÇÃO ENTRE ESPONTANEIDADE E VOLUNTARIEDADE. IRRELEVÂNCIA EM FACE DA REFORMA DO CÓDIGO PENAL DE 1984.

1. A reforma do Código Penal de 1984 modificou a base de reconhecimento da atenuante prevista em seu art. 65, III, "d", procurando o legislador beneficiar o agente que colabora com a celeridade da justiça na busca da verdade real, conforme se depreende da respectiva Exposição de Motivos item 55: "Beneficia-se, como estímulo à verdade processual, o agente que confessa espontaneamente, perante a autoridade, a autoria do crime, sem a exigência, em vigor, de ser a autoria 'ignorada ou imputada a outrem".

2. A confissão espontânea prevista no texto legal hoje é de caráter meramente objetivo, não fazendo a lei referência alguma a motivos ou circunstâncias que cercaram a prática do crime, incidindo a atenuante, assim, todas as vezes em que o acusado admitir sua participação na ação delituosa.

\section{Ordem concedida. ${ }^{50}$}

Destarte, não se pretende que a confissão seja fruto da iniciativa do réu, bastando que tenha sido feita por sua própria vontade, consoante o disposto na colenda jurisprudência:

AGRAVO REGIMENTAL. RECURSO ESPECIAL. DIREITO PENAL. PORTE ILEGAL DE ARMA DE FOGO. ART. 14 DA LEI N. 10.826/2003. ART. 65, III, D, DO CP.

CONFISSÃO VOLUNTÁRIA. RECONHECIMENTO DA ATENUANTE. DOSIMETRIA DA PENA. REFORMA DO ACÓRDÃO A QUO.

1. A teor do entendimento deste Superior Tribunal, a atenuante genérica da confissão, prevista no art. 65 ,

\footnotetext{
${ }^{50}$ Superior Tribunal de Justiça. HC 22.095/MS, Rel. Ministro PAULO GALLOTTI, SEXTA TURMA, julgado em 12/11/2002, DJ 04/08/2003, p. 433.
} 
III, d, do Código Penal, tem caráter objetivo, bastando que seja voluntária, não importando o caráter das situações em que foi efetivada a confissão.

2. O agravo regimental não merece prosperar, porquanto as razões reunidas na insurgência são incapazes de infirmar o entendimento assentado na decisão agravada.

3. Agravo regimental improvido. ${ }^{51}$

A confissão, como é cediço, pode se dar perante autoridade policial ou judiciária, e, em certos casos, em face do membro do Ministério Público.

Quando realizada em sede inquisitorial e retratada em juízo, não obsta o reconhecimento da atenuante genérica. Nesse sentido, é o disposto no julgado a seguir:

HABEAS CORPUS. CRIMES CONTRA O PATRIMÔNIO. DOSIMETRIA DA PENA. CONFISSÃO ESPONTÂNEA PERANTE A AUTORIDADE POLICIAL. RÉU QUE SE RETRATOU EM JUÍZO. CONFISSÃO EXTRAJUDICIAL QUE EMBASA O DECRETO CONDENATÓRIO. HARMONIA DA CONFISSÃO COM O CONJUNTO PROBATÓRIO. 1. "Toda pessoa acusada de um delito terá direito, em plena igualdade, a, pelo menos, as seguintes garantias:" (...) "g) de não ser obrigada a depor contra si mesma, nem a confessar-se culpada" (artigo 14, 3, "g", do Pacto Internacional sobre Direitos Civis e Políticos). Esse efetivo direito a não se auto-incriminar constitui uma das mais eminentes formas de densificação da garantia do processo acusatório e do direito à presunção de nãoculpabilidade. A revelar que o processo é o meio de plena demonstração da materialidade do delito e da autoria. 2. A confissão extrajudicial retratada em Juízo constitui circunstância atenuante (alínea "d" do inciso III do art. 65 do $\mathrm{CP}$ ), quando embasar a sen-

\footnotetext{
${ }^{51}$ Superior Tribunal de Justiça. AgRg no REsp 1521666/MG, Rel. Ministro Sebastião Reis Júnior, Sexta Turma, julgado em 02/06/2015, DJe 15/06/2015.
} 
tença penal condenatória. O que se deu no caso concreto. 3 . Ordem concedida. ${ }^{52}$

Requer-se, apenas, que, nestes casos, o juiz se valha da confissão retratada para embasar seu convencimento, segundo preleciona a ementa abaixo exposta:

PENAL E PROCESSO PENAL. AGRAVO REGIMENTAL EM RECURSO ESPECIAL. USO DE DOCUMENTO FALSO. DOSIMETRIA. CONFISSÃO ESPONTÂNEA PARCIAL.

UTILIZAÇÃO COMO SUPORTE DA CONDENAÇÃO. ATENUAÇÃO OBRIGATÓRIA.

DECISÃO MONOCRÁTICA. POSSIBILIDADE.

1. Nos termos da jurisprudência do Superior Tribunal de Justiça, se a confissão dos réus, ainda que parcial (qualificada) ou retratada, for utilizada pelo magistrado para fundamentar a condenação, deve incidir a respectiva atenuante (HC n. 237.252/SP, Ministra Maria Thereza de Assis Moura, Sexta Turma, DJe 26/2/2014).

2. Se a decisão recorrida estiver em manifesto confronto com a jurisprudência dominante deste Superior Tribunal, não há impedimento algum para o julgamento monocrático do recurso (art. 557, § 1. ${ }^{\circ}$-A, do CPC).

3. Agravo regimental improvido. ${ }^{53}$

Ademais, também não representa empecilho ao reconhecimento da atenuante prevista no artigo 65, inciso III, alínea "d", do Código Penal, a confissão denominada qualificada, isto é, aquela em que, não obstante o agente confitente admita a veracidade dos fatos delituosos imputados a si, alegue alguma circunstância que afaste sua responsabilidade penal, consoante a recente jurisprudência dos tribunais superiores:

AGRAVO REGIMENTAL NO HABEAS CORPUS. AMEAÇA E LESÃO CORPORAL COMETIDOS

\footnotetext{
${ }^{52}$ Superior Tribunal de Justiça. HC 91654, Relator Min. CARLOS BRITTO, Primeira Turma, julgado em 08/04/2008.

${ }^{53}$ Superior Tribunal de Justiça. AgRg no REsp 1442277/SP, Rel. Ministro SEBASTIÃO REIS JÚNIOR, SEXTA TURMA, julgado em 18/09/2014, DJe 07/10/2014.
} 
EM SITUAÇÃO DE VIOLÊNCIA DOMÉSTICA. CONFISSÃO QUALIFICADA.

POSSIBILIDADE DE RECONHECIMENTO DA ATENUANTE. CONSTRANGIMENTO ILEGAL EVIDENCIADO. RECURSO IMPROVIDO.

1. A jurisprudência do Superior Tribunal de Justiça admite que mesmo quando o autor confessa a autoria do delito, embora alegando causa excludente de ilicitude ou culpabilidade - a chamada confissão qualificada -, deve incidir a atenuante descrita no artigo 65, inciso III, alínea "d", do Código Penal.

2. Assim, tendo o paciente confessado o crime, mostra-se irrelevante ter agregado ao fato criminoso a tese da legítima defesa, sendo, portanto, devido o reconhecimento da referida atenuante.

3. Agravo regimental improvido. ${ }^{54}$

Nesse caso, assim como na hipótese anterior, faz-se mister apenas a utilização pelo magistrado da confissão como um dos elementos fundamentadores de seu convencimento.

Nesse diapasão, amealha-se a jurisprudência a seguir:

PENAL E PROCESSO PENAL. AGRAVO REGIMENTAL NO RECURSO ESPECIAL. 1. NEGATIVA DE VIGÊNCIA AO ART. 65, III, D, DO CP. VERIFICAÇÃO. CONFISSÃO QUALIFICADA. INCIDÊNCIA DA ATENUANTE. POSSIBILIDADE. 2. AGRAVO REGIMENTAL IMPROVIDO.

1. É assente no Superior Tribunal de Justiça que, ainda que se trate de confissão qualificada, deve sim incidir a atenuante prevista no art. 65 , inciso III, alínea d, do Código Penal, quando efetivamente utilizada como elemento de convicção .

2. Agravo regimental a que se nega provimento. ${ }^{55}$

A esse respeito, além do mais, o Superior Tribunal de Justiça, sedimentando ainda mais o entendimento ora exposto, editou a recente

\footnotetext{
${ }^{54}$ Superior Tribunal de Justiça. AgRg no HC 311.945/MS, Rel. Ministro Leopoldo De Arruda Raposo (Desembargador Convocado Do Tj/Pe), Quinta Turma, julgado em 30/06/2015, DJe 25/08/2015.

${ }^{55}$ Superior Tribunal de Justiça. AgRg no REsp 1392005/PR, Rel. Ministro Marco Aurélio Bellizze, Quinta Turma, julgado em 18/06/2014, DJe 27/06/2014.
} 
Súmula 545 que dispõe: "Quando a confissão for utilizada para a formação do convencimento do julgador, o réu fará jus à atenuante prevista no artigo 65, III, d, do Código Penal"56.

Desse modo, na prática, de acordo com a aplicação reiterada dos tribunais, são requisitos para o reconhecimento da confissão como circunstância atenuante genérica: ser voluntária, isto é, derivada de vontade própria, alheia a qualquer vício que a macule, tal qual a coação ou a tortura, mesmo que derive de sugestão de terceiros; ser realizada perante qualquer das autoridades competentes, ou seja, autoridade policial, judiciária ou membro do Ministério Público; ser utilizada como fonte de convencimento pelo magistrado.

\subsection{A RESPONSABILIDAdE PENAL PELA AUTOACUSAÇÃO FALSA}

Se por um lado a confissão, quando regular e verdadeira, representa um importante elemento probatório além de possibilitar ao agente confitente alguns benefícios, tal como a atenuação de sua pena, por outro, quando falsa, pode acarretar a sua responsabilização penal.

Conforme abordamos no terceiro capítulo, é de extrema importância, antes mesmo de observar a presença dos requisitos que conferem validade e credibilidade, a descoberta dos motivos que deram ensejo ao surgimento da confissão, porquanto não são raras as vezes em que eles indicam a ocorrência de uma confissão falsa, isto é, de uma autoacusação falsa.

Como bem assevera Rogério Greco,

São diversos os motivos que podem levar alguém a se autoacusar falsamente: razões de natureza pecuniária, mercenária, a exemplo daquele que recebe alguma vantagem para assumir um crime praticado por outra pessoa; espírito de sacrifício, quando um pai, por exemplo, diz ser o autor do crime cometido por seu filho; álibi, quando o agente, na verdade, quer se livrar das conseqüências de uma infração penal mais grave e, para isso, se autoimputa outra, menos grave,

\footnotetext{
56 Superior Tribunal de Justiça. Súmula 545, Terceira Seção, julgado em 14/10/2015, DJe $19 / 10 / 2015$.
} 
que, segundo o agente, aconteceu no mesmo dia e hora, só que em local muito distante do crime verdadeiro; exibicionismo, quando o agente quer ganhar reputação perante a bandidagem etc. ${ }^{57}$

Por isso, como forma de repulsa à autoacusação falsa, que tanto prejuízo causa à administração de nossa justiça, o artigo 341 do Código Penal, com sua redação original dada pelo Decreto-Lei 2848/1940, determina ser crime: "Acusar-se, perante a autoridade, de crime inexistente ou praticado por outrem",58.

Mais uma vez, Rogério Greco (2012, p. 589) assinala, acertadamente, os seguintes elementos do tipo penal em comento: "a) a conduta de se acusar; b) perante autoridade; c) de crime inexistente; d) ou praticado por outrem",59.

Alguns pontos merecem destaque.

Acerca da autoridade, é entendimento pacificado de que é competente apenas aquela com poderes investigativos.

De forma mais esclarecedora, assevera Cléber Masson que "encaixam-se nesse rol as autoridades policiais e judiciárias, bem como os membros do Ministério Público e os agentes administrativos dotados de atribuições para investigações criminais, a exemplo dos servidores da Receita Federal" ${ }^{\prime 60}$.

Quanto à extensão dessa responsabilidade penal, por sua vez, é imperioso consignar que apenas a autoacusação de crime configura o delito previsto no artigo 341 do Código Penal, ficando, destarte, aquele que se autoimputa a prática de uma contravenção penal impune.

Essa restrição, obviamente, merece nossas críticas. Ora, como bem prelecionam os mais variados estudiosos do direito penal, o que este tipo penal [autoacusação falsa] pretende é resguardar a administração da justiça, por isso, não há que se fazer um juízo de relevância.

Prosseguindo, vale dizer que o agente confitente que se autoacusa falsamente para livrar-se da responsabilidade penal de outro crime

\footnotetext{
${ }^{57}$ GRECO, Rogério. Curso de direito penal: parte especial. 8 ed. Niterói: Impetus, 2012. p. 589.

${ }^{59}$ GRECO, Rogério. Curso de direito penal: parte especial. 8 ed. Niterói: Impetus, 2012. p. 589.

${ }^{60}$ MASSON, Cleber. Código penal comentado. 2 ed. São Paulo: Método, 2014. p. 1244.
} 
mais grave não comete o delito de autoacusação falsa. Isso porque, neste caso, prevalece o direito do acusado de não incriminar a si mesmo.

Nessa direção, ponderam Celso Delmanto, Roberto Delmanto, Roberto Delmanto Junior e Fábio Machado de Almeida Delmanto (2002, p. 698-699):

$\mathrm{O}$ acusado que, na polícia ou em juízo, se auto-acusa de crime inexistente ou praticado por outrem, para se defender de outro delito que lhe é imputado, não comete o crime deste art. 341 do CP, em virtude das garantias constitucionais do direito ao silêncio $\left(\mathrm{CR} / 88\right.$, art. 5, LXIII e $\left.\S 2 .^{\circ}\right)$, de não ser obrigado a depor contra si mesmo, nem a confessar se (PIDCP, art. $14,3, \mathrm{~g})$ ou a declarar-se culpado $(\mathrm{CADH}$, art. $8,2, \mathrm{~g}) \cdot{ }^{61}$

Com efeito, destarte, aquele que confessa falsamente a prática de um crime inexistente ou do qual não participou, isto é, que imputa a si próprio a responsabilidade penal por algum fato criminoso deve ser penalmente responsabilizado, porquanto pode causar enormes problemas no deslinde justo do caso concreto, visto que a confissão, malgrado não mais seja considerada a rainha das provas, ainda encontra grande importância no processo penal brasileiro, em face, sobretudo, de sua constante incidência.

Assim, para a configuração do delito de autoacusação falsa como corolário da confissão inverídica depende, além do mais, de que a autoridade competente tome conhecimento e que a conduta de confessar falsamente seja feita de forma voluntária, isto é, ausente qualquer força alheia que a macule.

Compartilhando do mesmo pensamento, Cezar Roberto Bitencourt afirma ser "desnecessário registrar que a autoacusação deve ser voluntária (embora não seja necessária a espontaneidade), visto que se for

\footnotetext{
${ }^{61}$ DELMANTO, Celso; DELMANTO, Roberto; DELMANTO JUNIOR, Roberto; DELMANTO, Fabio Machado de Almeida. Código penal comentado. 6. ed. Rio de Janeiro: Renovar, 2002. p. 698699.
} 
forçada, motivada ou extorquida pela autoridade fica afastado o dolo, indispensável para a configuração típica"62.

Ante o exposto, portanto, entendemos ser o delito de autoacusação falsa, como corolário da confissão inverídica, um importante mecanismo de controle deste importantíssimo elemento de prova, garantindo a sua credibilidade e segurança.

Finalmente, convém amealhar os apontamentos de Cléber Masson:

Embora inexista hierarquia entre as provas, não se discute o alto valor prático da confissão, outrora chamada de "rainha das provas" (raegina probatum). Com a livre e espontânea autoacusação falsa, dificilmente o Poder Judiciário encontra meios para não condenar um inocente, muitas vezes deixando impune o verdadeiro e perigoso culpado. ${ }^{63}$

\section{CONCLUSÃO}

Concluindo, é possível constatar o quão importante é a confissão no processo penal e como se faz relevante um estudo mais pormenorizado.

A confissão, como se pôde perceber, ainda nos dias de hoje, representa um relevante meio de comprovação de culpa do acusado e, se utilizada corretamente, pode oferecer vantagens não somente àqueles responsáveis pela manutenção da justiça como àqueles que lhe deram origem.

\section{REFERÊNCIAS}

ARANHA, Adalberto José Q. T. de Camargo. Da prova no processo penal. 7. ed. São Paulo: Saraiva, 2006.

\footnotetext{
${ }^{62}$ BITENCOURT, Cezar Roberto. Tratado de direito penal: parte especial. 6 ed. São Paulo: Saraiva, 2012. p. 815.

${ }^{63}$ MASSON, Cleber. Código penal comentado. 2 ed. São Paulo: Método, 2014. p. 1245.
} 
AVENA, Norberto. Processo penal: esquematizado. 6. ed. São Paulo: Método, 2014.

BADARÓ, Gustavo Henrique Righi Ivaty; DINAMARCO, Marcio. Direito processual penal: tomo I. 2. ed. Rio de Janeiro: Elsevier, 2008.

BITENCOURT, Cezar Roberto. Tratado de direito penal: parte especial. 6. ed. São Paulo: Saraiva, 2012.

BONFIM, Edilson Mougenot. Curso de processo penal. 9. ed. São Paulo: Saraiva, 2014.

BRASIL, Constituição (1988). Constituição da República Federativa do Brasil. Brasília: Senado, 1988.

Ap. 4.072, TACrimSP, Rel. Toledo Assumpção, RT, 393:343.

Ap. 60.706, TACrimSP, Rel. Castro Garms.

Código de Processo Penal. Brasília: Senado, 1941.

Código Penal. Brasília: Senado, 1940.

Exposição de Motivos do Código de Processo Penal de 1941. DOU 13/10/1941.

. Superior Tribunal de Justiça. AgRg no Ag: 1410103 CE 2011/0129539-

2, Relator: Ministro JORGE MUSSI, Data de Julgamento: 07/11/2013, T5 QUINTA TURMA, Data de Publicação: DJe 21/11/2013.

Superior Tribunal de Justiça. AgRg no HC 311.945/MS, Rel. Ministro Leopoldo De Arruda Raposo (Desembargador Convocado Do Tj/Pe), Quinta Turma, julgado em 30/06/2015, DJe 25/08/2015.

Superior Tribunal de Justiça. AgRg no REsp 1392005/PR, Rel. Ministro Marco Aurélio Bellizze, Quinta Turma, julgado em 18/06/2014, DJe 27/06/2014.

Superior Tribunal de Justiça. AgRg no REsp 1442277/SP, Rel. Ministro SEBASTIÃO REIS JÚNIOR, SEXTA TURMA, julgado em 18/09/2014, DJe 07/10/2014.

. Superior Tribunal de Justiça. AgRg no REsp 1521666/MG, Rel. Ministro Sebastião Reis Júnior, Sexta Turma, julgado em 02/06/2015, DJe $15 / 06 / 2015$.

. Superior Tribunal de Justiça. AgRg no REsp: 1384067 SE 2013/0168525-0, Relator: Ministro MOURA RIBEIRO, Data de Julgamento: 06/02/2014, T5 - QUINTA TURMA, Data de Publicação: DJe $12 / 02 / 2014$.

Superior Tribunal de Justiça. HC 22.095/MS, Rel. Ministro PAULO GALLOTTI, SEXTA TURMA, julgado em 12/11/2002, DJ 04/08/2003, p. 433.

Superior Tribunal de Justiça. HC 91654, Relator Min. CARLOS BRITTO, Primeira Turma, julgado em 08/04/2008

Superior Tribunal de Justiça. HC: 50304 RJ 2005/0195129-6, Relator:

Ministro PAULO MEDINA, Data de Julgamento: 17/08/2006, T6 - SEXTA TURMA, Data de Publicação: DJ 25.09.2006 p. 313. 
. Superior Tribunal de Justiça. Súmula 545, Terceira Seção, julgado em 14/10/2015, DJe 19/10/2015. . TACrim, Rel. Bento Mascarenhas, RT, 729:583.

Tribunal de Justiça do Estado de São Paulo. APL: 30029971420138260562 SP 3002997-14.2013.8.26.0562, Relator: Souza Nery, Data de Julgamento: 06/08/2015, $9^{\text {a }}$ Câmara de Direito Criminal, Data de Publicação: 10/08/2015.

DELMANTO, Celso; DELMANTO, Roberto; DELMANTO JUNIOR, Roberto; DELMANTO, Fabio Machado de Almeida. Código penal comentado. 6. ed. Rio de Janeiro: Renovar, 2002.

GRECO FILHO, Vicente. Manual de processo penal. 9. ed. São Paulo: Saraiva, 2012.

GRECO, Rogério. Curso de direito penal: parte especial. 8. ed. Niterói: Impetus, 2012.

LOPES JUNIOR, Aury. Direito processual penal. 11. ed. São Paulo: Saraiva, 2014.

MARCÃO, Renato. Curso de processo penal. São Paulo: Saraiva, 2014.

MASSON, Cleber. Código penal comentado. 2. ed. São Paulo: Método, 2014.

NUCCI, Guilherme de Souza. Manual de processo penal e execução penal. 11. ed. Rio de Janeiro: Forense, 2014.

. O valor da confissão como meio de prova no processo penal. São Paulo: Revista dos Tribunais, 1997.

ROSSETTO, Enio Luiz. A confissão no processo penal. 1. ed. São Paulo: Atlas, 2001.

TÁVORA, Nestor; ALENCAR, Rosmar Rodrigues. Curso de direito processual penal. 6. ed. Salvador: Juspodivm, 2011.

TOURINHO FILHO, Fernando da Costa. Manual de processo penal. 16. ed. São Paulo: Saraiva, 2013. 